\title{
Serum studies of leucocyte elastase in acute and chronic lung diseases
}

\author{
RA STOCKLEY, K OHLSSON \\ From the General Hospital, Birmingham and Department of Surgery, Malmö General Hospital, Malmö, \\ Sweden
}

ABSTRACT Immunoreactive leucocyte elastase was measured in the serum of patients with chronic obstructive bronchitis. No evidence was found to demonstrate the release of this enzyme in the pulmonary circulation. However the average serum concentrations $(573.0 \mu \mathrm{g} / \mathrm{l} ; \mathrm{SD} \pm 261 \cdot 0)$ were higher $(2 \mathrm{p}<0.001)$ in this group of patients than in age matched control subjects $(355.2 \mu \mathrm{g} / \mathrm{l}$; $\mathrm{SD} \pm 274 \cdot 8)$. Further studies confirmed this finding but patients with other active lung diseases had similarly increased leucocyte elastase concentration in the serum. This suggests that a raised serum leucocyte elastase concentration is a feature of active lung diseases and not a feature of obstructive bronchitis alone.

Pulmonary emphysema is thought to be the result of destruction of lung elastin by elastolytic enzymes. ${ }^{1}$ Leucocyte elastase (LE) is one of the enzymes implicated because it is found within the lung ${ }^{2} 3$ and is capable of producing emphysema in experimental animals. ${ }^{4}$

Several authors have demonstrated that the leucocytes of some patients with emphysema contain greater quantities of LE than subjects with normal lungs. ${ }^{5-}$ They have suggested that this increased potential source of enzyme may play a role in the pathogenesis of the lung disease.

However, for LE to be of importance in the development of emphysema it must be released from the leucocyte and remain active within the lung for sufficient time to digest lung elastin. Once the enzyme enters the general circulation it is rapidly inactivated by inhibitors such as alpha ${ }_{1}$-antitrypsin by the formation of stable enzyme-inhibitor complexes. Direct studies of the release of LE within the pulmonary circulation in man have yet to be performed. For this reason, we undertook a limited study in patients with severe obstructive bronchitis using a sensitive and specific radioimmunoassay that can detect LE even when complexed with alpha ${ }_{1}$-antitrypsin, ${ }^{8}$ to see if we could detect the release of LE within the pulmonary circulation.

In the course of this study, it was noted that the serum concentration of LE was higher in the patients

Address for reprint requests: Dr RA Stockley, The General Hospital, Steelhouse Lane, Birmingham B4 6NH. than in normal blood donors studied previously. ${ }^{8}$ We extended the study to determine whether the high circulating LE concentrations were a feature unique to the patients we had investigated and could therefore be implicated in their disease.

\section{Methods}

\section{STUDY A PULMONARY ARTERIOVENOUS} STUDY

The investigative procedure has been described in detail elsewhere. ${ }^{9}$ In brief, 20 patients with chronic obstructive bronchitis and cor pulmonale were studied while undergoing right heart catheterisation as part of their clinical investigation. Ten $\mathrm{ml}$ of blood was taken simultaneously from the pulmonary and systemic arteries, allowed to clot and centrifuged to obtain the serum. All samples were stored at $-70^{\circ} \mathrm{C}$ until analysed.

STUDY B SERUM STUDY

Ten $\mathrm{ml}$ of venous blood was taken from several groups of subjects.

Control subjects: 61 subjects with no clinical or physiological evidence of lung disease. They consisted of laboratory technicians and outpatients seen two to three months after an uncomplicated myocardial infarction. A record was made of smoking history and cough and sputum production. Chronic obstructive bronchitis: 62 patients in the stable clinical state were collected from the outpatient department. All had chronic cough with sputum 
production and marked irreversible airways obstruction.

"Emphysema": these patients were similar to those in the chronic obstructive bronchitis group. All had marked irreversible airways obstruction. However, in contrast they had little or no sputum production and radiological features of hyperinfiltration. ${ }^{10}$

Infected subjects: serum was taken from 35 subjects within five days of admission to hospital with an acute respiratory tract infection. This was defined as a cough productive of purulent sputum, pyrexia, and shortness of breath. All subjects had a positive bacterial culture from the sputum. Twenty had chronic obstructive bronchitis. The remaining 15 had no history of lung disease and normal lung function to conventional testing (lung flow rates, volumes, and transfer factor).

Cystic fibrosis: 20 patients were studied from the Cystic Fibrosis Clinic at the Brompton Hospital, London. All had a positive family history or positive sweat test or both. The patients had chronic lung disease with cough and sputum production.

Fibrosing alveolitis: 14 patients with idiopathic fibrosing alveolitis were studied shortly after presentation with the disease. All had classical restrictive lung disease on conventional pulmonary function testing, bilateral fine basal crepitations in the chest and bilateral interstitial shadowing on the chest radiograph.

Once collected, all samples were coded, stored in dry ice and flown to Malmö in Sweden where they were assayed without knowledge of the patient groups or individual sample allocation.

Serum LE was measured using a radioimmunoassay described previously. ${ }^{8}$ The lower limit of detection was $20 \mu \mathrm{g} / \mathrm{l}$ and the between-batch coefficient of variation was $7 \cdot 5 \%$. Previous studies have shown that $85 \%$ of the immunoreactive elastase is measured with this assay despite being complexed with its inhibitors in serum. The signicance of any difference between groups was assessed using the Wilcoxon-Mann-Whitney rank-sum test for non parametric data. The results of study A were tested using the Wilcoxon signed rank test for paired differences.

\section{Results}

STUDY A ARTERIOVENOUS STUDY The mean age of subjects in this group was 56.0 years (SD $\pm 6.9 \mathrm{yr}$ ). The average ratio of forced expired volume in one second to forced vital capacity (FEV FVC) $_{1}$ ) was $31.9 \%$ (SD \pm 8.2 ), total lung capacity was $105.6 \%$ (SD \pm 20.0$)$ of predicted value for age and height ${ }^{11}$ and transfer factor for carbon monoxide $79 \cdot 1 \%$ predicted (SD \pm 26.9 ).

The average concentration of LE in peripheral arterial blood was $573.0 \mu \mathrm{g} / \mathrm{l}(\mathrm{SD} \pm 261.0)$ compared with the pulmonary arterial value of $540.8 \mu \mathrm{g} / \mathrm{l}$ (SD $\pm 166 \cdot 0)$. This difference was not statistically significant $(2 p>0.05)$.

\section{STUDY B SERUM STUDY}

The average values for LE concentration in each of the subject groups are summarised in the table together with the age and $F E V_{1} / F V C$ ratio. Individual values are shown in the figure.

There was no difference between the LE concentrations of normal smokers (mean $297.2 \mu \mathrm{g} / \mathrm{l}$ SD \pm 216.6) and non-smokers (mean 332.1 ug/l; SD \pm $306.3)(n=34$ and 27 respectively; $2 p>0.05)$. Subjects with normal lung function $\left(\mathrm{FEV}_{1} / \mathrm{FVC}=\right.$ $74.5 \%$; SD \pm 5.9 ) but chronic cough and sputum production $(\mathrm{n}=38$; mean age $=54 \cdot 2$ years, $\mathrm{SD} \pm$ 11.2) had serum LE concentrations similar to the remaining control subjects $(347 \cdot 5 \mu \mathrm{g} / 1 \pm 274 \cdot 8)$.

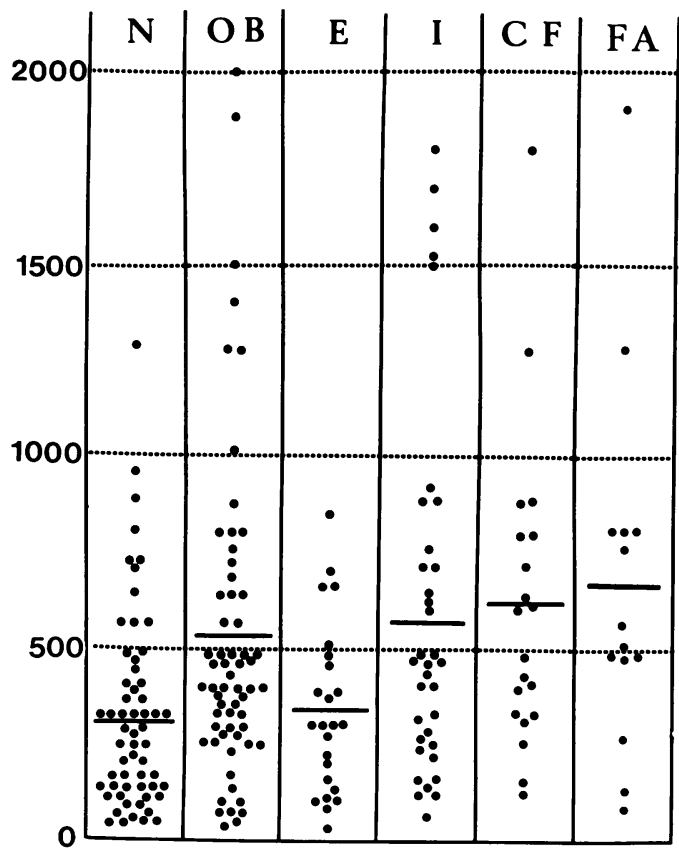

SERUM LEUCOCYTE ELASTASE

$$
(\mu \mathrm{g} / \mathrm{l})
$$

Figure Individual serum LE concentrations are shown in $\mu \mathrm{g} / \mathrm{l}$. The results are divided into patient groups: $N=$ subjects with "normal" lungs; $O B=$ obstructive bronchitis; $E=$ "emphysema"; $C F=$ cystic fibrosis; $F A=$ fibrosing alveolitis. The horizontal solid lines are the mean values for each group. 
Table The average age and leucocyte elastase concentration is shown for each subject group

\begin{tabular}{|c|c|c|c|c|c|}
\hline Subject group & Age (years) & $F E V_{1} / F V C(\%)$ & $\begin{array}{l}\text { Leucocyte elastase } \\
(\mu \mathrm{g} / \mathrm{l})\end{array}$ & $\begin{array}{l}\text { Significance of difference } \\
\text { from normal }(2 p)\end{array}$ & $\begin{array}{l}\text { Significance of difference } \\
\text { from obstructive bronchitis } \\
(2 p)\end{array}$ \\
\hline $\begin{array}{l}\text { Normal } \\
(n=61)\end{array}$ & $\begin{array}{c}43.9 \\
(16.5)\end{array}$ & $\begin{array}{c}74 \cdot 5 \\
(5.9)\end{array}$ & $\begin{array}{c}312 \cdot 7 \\
(258 \cdot 4)\end{array}$ & & $<0.0025$ \\
\hline $\begin{array}{l}\text { Obstructive bronchitis } \\
(n=62)\end{array}$ & $\begin{array}{c}59 \cdot 4 \\
(9 \cdot 1)\end{array}$ & $\begin{array}{l}39 \cdot 6 \\
(10 \cdot 0)\end{array}$ & $\begin{array}{l}(250.4) \\
513 \cdot 6 \\
(417 \cdot 4)\end{array}$ & $<0.0025$ & \\
\hline $\begin{array}{l}\text { "Emphysema" } \\
(\mathrm{n}=25)\end{array}$ & $\begin{array}{c}58 \cdot 2 \\
(10 \cdot 5)\end{array}$ & $\begin{array}{l}39 \cdot 3 \\
(12 \cdot 7)\end{array}$ & $\begin{array}{l}351 \cdot 8 \\
(214 \cdot 4)\end{array}$ & NS & NS \\
\hline $\begin{array}{l}\text { Chest infection } \\
(n=35)\end{array}$ & $\begin{array}{l}59 \cdot 4 \\
(14 \cdot 9)\end{array}$ & & $\begin{array}{c}616 \cdot 9 \\
(474 \cdot 2)\end{array}$ & $<0.001$ & NS \\
\hline $\begin{array}{l}\text { Cystic fibrosis } \\
(n=20)\end{array}$ & $\begin{array}{c}21 \cdot 3 \\
(6 \cdot 3)\end{array}$ & $\begin{array}{c}58 \cdot 1 \\
(15 \cdot 7)\end{array}$ & $\begin{array}{c}614 \cdot 9 \\
(399 \cdot 1)\end{array}$ & $<0.001$ & NS \\
\hline $\begin{array}{l}\text { Fibrosing alveolitis } \\
(n=14)\end{array}$ & $\begin{array}{c}53 \cdot 0 \\
(15 \cdot 5)\end{array}$ & & $\begin{array}{c}663 \cdot 2 \\
(473 \cdot 0)\end{array}$ & $<0.01$ & NS \\
\hline
\end{tabular}

$\mathrm{n}=$ number studied in each group.

NS = not significant.

Figures in parentheses are $1 \mathrm{SD}$.

Patients with obstructive bronchitis had higher serum concentrations of LE than bronchitis subjects with normal $\mathrm{FEV}_{1}$ as described above $(2 \mathrm{p}<0.025)$ as well as the normal subjects and those called "emphysema" (table). However, the average LE concentration of patients with acute infection, cystic fibrosis and fibrosing alveolitis were similar to the patients with obstructive bronchitis (table).

The infected patients had higher LE concentrations than "normal subjects" (table). This difference remained for both the infected subjects with normal lung function upon recovery (mean $\mathrm{LE}=566.9$ $\mu \mathrm{g} / 1 ; \mathrm{SD} \pm 379.4: 2 \mathrm{p}<0.01)$ and the bronchitic subjects with infection (mean $\mathrm{LE}=654.4 \mu \mathrm{g} / \mathrm{l}$; $\mathrm{SD} \pm 541 \cdot 1: 2 \mathrm{p}<0 \cdot 01)$.

There was no clear relationship between LE concentration and age. Normal subjects under the age of 35 years (mean $=26 \cdot 1$ years; $S D \pm 4 \cdot 7$ ) had LE concentrations similar to normal subjects over 35 years age (mean 54.8 years; $S D \pm 10 \cdot 4$ ). The average values were $242.4 \mu \mathrm{g} / \mathrm{l}$; $(\mathrm{SD} \pm 212.0$; $\mathrm{n}=23)$ and $355 \cdot 2 \mu \mathrm{g} / \mathrm{l} ;(\mathrm{SD} \pm 274 \cdot 8 ; \mathrm{n}=38$ : $2 p>0.05)$ respectively. Similarly the significance of differences seen between subject groups remained unaltered by more careful age matching.

\section{Discussion}

The initial study (study A) failed to demonstrate the release of LE into the serum as blood transverses the lung in patients with chronic obstructive bronchitis even though these patients are likely to have emphysema of variable severity. ${ }^{12}$ This could be for several reasons. Firstly it is possible that LE is not released into the pulmonary circulation in these patients or it is in quantities below the sensitivity of the current assay. Secondly such enzyme release may be intermittent rather than continuous, and thirdly any LE released within the lung vasculature may become rapidly bound to lung elastin ${ }^{4}$ and therefore not enter the circulation in measurable amounts.

The results of the subsequent serum study (study B) showed a wide range of values for serum leucocyte elastase in both normal subjects and those with lung disease. The inclusion of subjects seen after myocardial infarction is unlikely to have affected the "normal" range since they were indistinguishable from the remaining subjects.

Patients with chronic obstructive bronchitis had higher circulating concentrations of LE than subjects with normal lungs. This finding would support the hypothesis that their disease may be related to release of this enzyme. It has been suggested that emphysema is the result of an imbalance between enzymes and inhibitors. ${ }^{1}$ Many of the patients studied here will have pathological emphysema ${ }^{12}$ and the results would support the concept that excess release of LE could be the reason for their disease.

However, the explanation is probably more complex since the group we have called "emphysema" had serum LE levels similar to the control group. It is possible that this "emphysema" group have no pathological emphysema since the radiographic appearances do not necessarily imply the presence of the disease. ${ }^{13} \mathrm{An}$ alternative explanation may be that the severity and time course of the disease varies from subject to subject and consequently the release of enzyme could also be widely variable, intermittent, or have occurred some time previously, the disease process being static at the time of study.

Patients with other active lung diseases also had raised serum LE concentrations compared with the control subjects. These diseases are not typically associated with widespread emphysema. This suggests that an increase in serum LE is a non-specific finding in patients with a wide variety of active lung diseases and not a feature of patients with obstructive bronchitis alone. 
High serum levels of LE in disease states probably reflect greater release of the enzyme into the circulation since the enzyme is cleared rapidly by the reticulo endothelial system. ${ }^{14}$ However there may be individual variations in the rate of clearance which could alter the absolute amounts of LE within the blood. Further studies will be necessary to clarify this point.

If the proteolytic theory of emphysema is correct the present results suggest that an increased release of LE alone does not account for the disease. The site of release of the enzyme, a defect of protective inhibitors and the affinity of the enzyme for its substrate may all be important in determining the pathological result. It may be more fruitful to study the balance between enzymes and inhibitors within the lungs and their secretions rather than in the systemic circulation ${ }^{3}$ in order to understand the pathogenesis of pulmonary emphysema.

We would like to thank Jane Downs for typing the manuscript. RA Stockley was in receipt of grants from the Medical Research Council, Boehringer Ingelheim, The Endowment Fund and the West Midlands Regional Health Authority. The study was also supported by grants from the Swedish Medical Research Council (project no B80-17X03910-08B), Senior Researcher K Ohlsson, the Swedish Association against Cancer (project no 1300-B80-02XA), the Medical Faculty, University of Lund, the Foundation of Torsten and Ragnar Söderberg, the Foundation of Malmö General Hospital against Cancer, the Foundation of John and Augusta Persson, and the Foundation of Thorsten and Elsa Segerfalk. We are grateful to Dr $\mathbf{J}$ Batten for permission to study some of the patients with cystic fibrosis under his care.
References

${ }^{1}$ Anon. The pathogenesis of pulmonary emphysema. Lancet 1980;1:743-5.

${ }^{2}$ Ohlsson K, Tegner H. Granulocyte collagenase, elastase and plasma protease inhibitors in purulent sputum. Eur J Clin Invest 1975;5:221-7.

${ }^{3}$ Stockley RA, Burnett D. Alpha ${ }_{1}$ antitrypsin and leukocyte elastase in infected and non-infected sputum. Am Rev Respir Dis 1979;120:1081-6.

${ }^{4}$ Janoff A, Sloan B, Weinbaum G et al. Experimental emphysema induced with purified human neutrophil elastase. Tissue localization of the instilled protease. Am Rev Respir Dis 1977;115:461-78.

${ }^{5}$ Kramps JA, Bakker W, Dijkman JH. A matched-pair study of leukocyte elastase-like activity in normal persons and in emphysematous patients with and without alpha $_{1}$-antitrypsin deficiency. Am Rev Respir Dis 1980; $121: 253-61$.

${ }^{6}$ Rodriguez JR, Seals JE, Radin A, Lin JS, Mandl I, Turino GM. Neutrophil lysosomal elastase activity in normal subjects and in patients with chronic obstructive pulmonary disease. Am Rev Respir Dis 1979;119:409-17.

' Lam S, Abboud RT, Chan-Yeung M, Rushton JM. Neutrophil elastase and pulmonary function in subjects with intermediate alpha ${ }_{1}$-antitrypsin deficiency (MZ phenotype). Am Rev Respir Dis 1979;119:941-51.

${ }^{8}$ Ohlsson K, Olsson A-S. Immunoreactive granulocyte elastase in human serum. Hoppe Seyler's $Z$ Physiol Chem 1978;359:1531-9.

${ }^{9}$ Stockley RA, Burnett D, Bradwell AR. An arteriovenous study of serum $\alpha_{1}$ antitrypsin in patients with chronic bronchitis. Clin Chim Acta 1978;88:127-33.

${ }^{10}$ Simon G. Radiology and emphysema. Clin Radiol 1964; $15: 293-306$.

11 Cotes JE. Lung Function. Fourth edition. Oxford: Blackwell Scientific Publications, 1979:377-8.

12 Thurlbeck WM. Chronic airflow obstruction in lung disease. Philadelphia: WB Saunders Company, 1976.

${ }^{13}$ Thurlbeck WM, Simon G. Radiologic appearance of the chest in emphysema. Am J Roent 1978;130:429-40.

${ }^{14}$ Ohlsson K, Laurell C-B. The disappearance of enzymeinhibitor complexes from the circulation of man. Clin Sci Mol Med 1976;51 :87-92. 